MPIfG Working Paper 01/8, December 2001

\title{
The Transformation of Corporate Organization in Europe: An Overview ${ }^{1}$
}

\author{
by Wolfgang Streeck (streeck@mpifg.de)
}

Prof. Wolfgang Streeck is Director at the Max Planck Institute for the Study of Societies, Cologne.

Published in French as: La transformation de l'organisation de l'entreprise en Europe: Une vue d'ensemble. In: Robert M. Solow (dir.), Institutions et croissance: Les chances d'un modèle économique européen. Paris: Bibliothèque Albin Michel Économie, 2001, 175-230.

\begin{abstract}
Very large firms, the rising significance of small and medium-sized enterprises notwithstanding, still account for most of the employment and wealth creation in Europe and will continue to do so for the foreseeable future. They also to a large extent determine the political institutions that regulate the relationship between economy and society, in particular the status of workers and the way in which the public interest is brought to bear on the economy. This overview on the current transformation of corporate organization in Europe begins by asking whether there is in fact a European model of the large firm, despite the considerable differences that exist between European countries, and to what extent European integration is likely to bring about convergence on a more uniform pattern. Next, it reviews the changes in the organization of large European firms and in corporate governance in Europe during the 1990s, which took place in response to the evolution of two of the major "task environments" of firms, product markets and financial markets. Third, the paper discusses the consequences of corporate transformation for the social embeddedness of large European firms, especially the challenges posed by the ongoing changes in corporate organization to European systems of industrial citizenship of workers and to the capacity of European states and governments to hold large firms socially accountable. In conclusion, the paper emphasizes the growing autonomy of large firms as strategic actors and comments on the problems of corporate adjustment under high and endemic uncertainty.
\end{abstract}

\section{Zusammenfassung}

Trotz der steigenden Bedeutung von kleinen und mittleren Unternehmen sind Großunternehmen weiterhin die wichtigste Quelle von Beschäftigung und Wohlstand in Europa. Dies wird sich in absehbarer Zukunft nicht ändern. Großunternehmen haben auch erheblichen Einfluss auf die politischen Institutionen, die das Verhältnis zwischen Wirtschaft und Gesellschaft regeln, vor allem den Status von Arbeitnehmern und die Art und Weise, wie öffentliche Interessen gegenüber der Wirtschaft zur Geltung gebracht werden. Ausgangspunkt der Überlegungen des Papiers über die gegenwärtigen Veränderungen in der Organisation europäischer Großunternehmen ist die Frage, ob es ungeachtet beträchtlicher nationaler Unterschiede ein europäisches Modell der

Unternehmensorganisation gibt bzw. inwieweit die europäische Integration zu einer Konvergenz auf ein einheitlicheres System führen wird. Das Papier beschreibt die während der Neunzigerjahre eingetretenen Veränderungen in der Organisation großer europäischer Unternehmen und in den nationalen Systemen der "Corporate Governance" und erklärt diese als Antwort auf den Wandel der beiden entscheidenden Unternehmensumwelten, der Produkt- und Finanzmärkte. Anschließend werden die Auswirkungen des Strukturwandels der großen Unternehmen auf deren soziale Einbettung diskutiert, und zwar insbesondere die von ihm ausgehenden Herausforderungen für die nationalen Systeme industrieller Bürgerrechte sowie die Fähigkeit europäischer Staaten und Regierungen, gegenüber großen Unternehmen auf deren gesellschaftlichen Verpflichtungen zu bestehen. In der Schlussbetrachtung wird die wachsende Autonomie großer Unternehmen als strategische Akteure 


\section{Contents}

$1 \quad$ A European Model of Corporate Organization?

1.1 Corporate Organization in Europe

1.2 Europeanization of Corporate Governance in Europe?

2 Corporate Adjustment to Changing Product and Financial Markets

2.1 Product Markets: Internationalization, Technological Change, and Intensified Competition

2.2 Financial Markets: Internationalization and Pressures for "Shareholder Value"

2.3 National States: Changes in Corporate Governance and Financial Regimes

$3 \quad$ Challenges to Industrial Citizenship and Public Accountability

3.1 Industrial Citizenship Under Market Pressure

3.1.1 The Report of the German Co-Determination Commission

3.1.2 Competitiveness and Shareholder Value: Strains on Industrial Citizenship and Labor-Management Cooperation?

3.1.2.1 Industrial Citizenship and Competitiveness

3.1.2.2 Industrial Citizenship and Shareholder Value

3.1.3 Product and Capital Market Niches for Stakeholder Firms?

3.1.4 From Legal Prescription to Voluntary Negotiation: Increasing Variety Within National Regimes

3.1.5 Industrial Citizenship as a Limiting Condition for Organizational

3.2 Modernization?

4 Corporate Accountability in an International Economy

Convergence, Comparative Advantage, and Strategic Choice: Corporate Change Under Uncertainty

References

\section{A European Model of Corporate Organization? 1.1 Corporate Organization in Europe}

The standard literature on corporate governance analyses the relationship between shareholders and management (Shleifer and Vishny 1996). More specifically, it is about institutional arrangements within corporations by which shareholder "principals" may best control their managerial "agents", to prevent the latter from diverting the resources entrusted to them to purposes other than the maximization of shareholder return (Fama 1980). The underlying assumption is that company efficiency is inversely related to the extent to which the interests of owners are diluted by the interests of management in the conduct of business. In other words, corporate governance as a concern of mainstream institutional economics is about both the efficient use of resources as well as about reassurance for investors against interference of management or other interests with their property rights (its main subject being "how investors get their money back").

Standard theories of corporate governance reflect a situation of separation of ownership and control, in which share ownership is widely dispersed and management, facing a myriad of small shareholders, is potentially in a position to run the company in line with its own preferences ("managerial capitalism"; Berle and Means 1999). This is a situation 
that has historically prevailed in liberal capitalism, especially in the United States and Great Britain. Indeed corporate governance, the way it is normally defined, is strictly speaking an Anglo-American concept. On the European Continent, where ownership was and still is much less dispersed than in Anglo-American countries (Becht and Roel 1999; La Porta et al. 1998), the relationship between investors and management has traditionally been quite different. Moreover, the Continental-European view of the corporation recognizes a public interest in the management of large firms (Donnelly et al. 2000), as well as includes legally based or collectively negotiated systems of industrial citizenship of workers to be balanced and reconciled with the interests of investors and of the public (Jackson 2001b).

- Historically, ownership in Continental-European firms was more concentrated than in the U.S. and the UK, which made for closer relations between owners and managers (Beyer 1999). Management power was derived from the support of large shareholders (Apeldoorn 2000), while managerial independence was sometimes rooted in corporate law passed by governments to foster better, more professional management in order to ensure high performance of the national economy. It also arose from the need for managers to balance the interests of shareholders and interventionist governments, as well as of other organized groups such as labor. Bank ownership of stock, crossshareholding between companies and public ownership of shares protected holders of large blocks of capital from being surprised by anonymous market forces. Financial systems helped make corporations and their managers independent from the capital market as companies were able to finance themselves primarily from bank credit and retained earnings, as opposed to selling equity; above all, a market for corporate control was missing as there were strong protections, of various sorts, against hostile takeover. With capital more patient and less interested in short-term returns, management in Continental-European firms came to see itself as a mediator between different interest groups inside and outside the company, rather than an agent of owners or, alternatively, a self-seeking interest group of its own. While this situation is changing today, as will be pointed out further down, differences between Continental Europe and the Anglo-American world in corporate ownership and finance are still strong.

- Industrial citizenship of workers refers to rights of workforces to be involved on a continuous basis in the management of firms. Such rights - to information, consultation, or co-decision-making ("co-determination") - may have originated in employer paternalism or socialist trade unionism; usually they represent a compromise between the two. Also, industrial citizenship may be based in labor law, company law, or both. The way industrial citizenship is institutionalized differs considerably between European countries; for example, arrangements as they have historically evolved may or may not include unions and collective bargaining, and workforce rights may be weak, like in France, or strong, like in Germany. Still, the legal order of most Continental-European countries recognizes a stake of workers in the firm in which they are employed, and a right of workforces to some form of voice in management. This differs from the more liberal Anglo-American countries where labor is not recognized as a permanent interest in the firm and is as a consequence mostly reduced to exit to the external labor market as its principal way of expressing discontent with company management.

- While Continental-European legal orders do protect the rights of shareholders, they often also recognize an interest of the public in good and orderly management and high economic performance that is not assumed to be necessarily identical with 
shareholder interests. In most Continental-European countries, corporations are considered not just private associations of shareholders, the public interest being limited to protection of the latter against fraud or misrepresentation of facts. Instead they are treated as "constitutional associations" whose internal structures of decisionmaking are a matter of public concern (Donnelly et al. 2000). Good corporate governance in the Continental-European sense is one that ensures an equitable and socially beneficial balance between the interests of the various stakeholders in the corporation, protecting social peace and enabling the firm to function in harmony with its social environment. Put otherwise, corporations are seen as having obligations, not just to their shareholders, but also to society-at-large - for example in skill formation, equal treatment of women and minorities, and environmental protection - that go beyond Anglo-American notions of voluntarily accepted "corporate responsibility". As a consequence, governments assume a right to intervene in the internal structures and governance arrangements of corporations, in order to institutionalize the public obligations of firms within their internal bargaining or decision-making arrangements.

Is corporate organization in Europe informed by a European model of corporate organization? Given the close similarities between the UK and the U.S., it is clear that if a "European model" exists, it can only be a Continental-European one (cf. Mayer 2001). Even within Continental Europe, corporate organization is embedded in distinctive national institutions and traditions making for considerable diversity between legal regimes as well as between firms of different national origin. Still, Anglo-American theories of corporate governance, focusing as they do exclusively on the shareholdermanagement nexus in disregard of the interests of the public and the workforce, do neglect important aspects of corporate organization that most Continental-European countries have in common. Continental models of the large firm - German law uses the felicitous concept of an "enterprise constitution" (Unternehmensverfassung) - tend to envisage a stakeholder firm in which not just owners but also workers and the public-atlarge have legitimate interests that need to be reflected in a firm's organization and behavior. The prominence of issues of corporate governance, conventionally defined, in the Continental-European debate today reflects pressures, from capital markets and elsewhere, to abandon a model of the firm that includes a plurality of stakeholders, in favor of a monistic model in which only shareholder interests are considered legitimate. It also propagates a concept of economic efficiency that requires the exclusion of all interests other than those of shareholders from direct influence upon, or internal representation in, company management.

\subsection{Europeanization of Corporate Governance in Europe?}

For some time well into the 1980s, progress in European integration was expected to eliminate the differences between national systems of company law and industrial citizenship, by absorbing the latter into a unified European system. But attempts at institutional harmonization consistently failed as national differences, even excluding the U.K., proved too wide to be reconcilable. Today harmonization is no longer being seriously pursued. Whereas European legislative proposals now focus on the coordination of national regimes and the standardization of the interfaces between them, what used to be regarded as inefficient legal fragmentation is increasingly seen as an opportunity for healthy regime competition and innovative institutional and organizational experimentation in a period of economic and technological uncertainty. Indeed while remaining firmly rooted in divergent national systems of corporate law and workforce participation, multinational European companies have increasingly acquired a capacity to 
operate comfortably within a plurality of national regimes, moving between them for regime arbitrage or creating their own individual patchworks of national institutional environments to exploit different comparative advantages.

In the area of company law, efforts to enact a statute for a European Company (Societas Europea, SE) date back to the early 1970s. At the time, governments and large firms were convinced that an integrated European economy could not exist without a unified legal framework for corporate governance. However, successive proposals remained unsuccessful, largely because it proved ultimately impossible to accommodate the postwar German system of co-determination at enterprise level. The first drafts of a "Fifth Directive" on company law aimed at extending the German co-determination regime to the rest of Europe; this was resisted by business - including German business - as well as by many governments and most trade unions. Subsequent weaker proposals, in order to secure German support, had to include safeguards preventing German firms from exiting co-determination by incorporating in European law; this turned out to be technically too difficult. Still later drafts referred to multinational firms only and offered menus of supposedly functionally equivalent systems of workforce representation on company boards, from which governments were to select a regime close to their national tradition to be made obligatory for firms based in their countries. In the second half of the 1990s, the Davignon committee still further reduced the scope of the proposed legislation to mergers and joint ventures, leaving it to the firms involved to negotiate with their workforces the extent of board representation, above a fallback minimum level and with ample provisions to protect existing national practice. The Davignon proposal failed at the Cologne meeting of the European Council in 1999. By that time, however, an unprecedented wave of cross-national mergers and acquisitions had been under way for a number of years, apparently unimpeded by the lack of a European company statute.

Still, efforts to create a European Company Statute continue. But whatever will result, if at all, will stop far short of legal harmonization, and in this respect it will be in line with the general thrust of European integration in the 1990s. Like Davignon, the proposal that was provisionally adopted at the Nice summit is restricted to mergers and joint ventures. Rather than undertaking to regulate worker participation as such, all it undertakes to do is reconcile different national systems of participation if firms from two or more European countries create a common business, so to facilitate transactions across the borders between divergent national regimes that are allowed to remain exactly the way they are. In particular, to protect German co-determination - the sticking point of all past initiatives - the Nice compromise stipulates that unless the workers and managements involved agree to a different solution, a merged company or a joint venture incorporated in European law must adopt the highest level of participation existing in the countries involved. It will have to be seen what the protests of German firms will achieve, which complain that the Nice solution will disadvantage them in the market for inter-firm cooperation across European borders.

In any case, indications are that over the years, pressures for harmonization of company law at the European level have abated considerably, and not only because firms have to a surprising extent learned to live with different national regimes and even benefit from their diversity. Two other, perhaps related factors seem of importance. First, national states competing with one another and acting on their own changed their rules, especially in the area of financial regulation, to enable firms based on their territory to adjust to new market pressures and take advantage of new economic opportunities. More often than not, parallel national reforms in response to the internationalization of financial markets in particular seem to have preempted supranational legislation or made it less essential for 
the conduct of business. Second, during the 1990s many national regimes seem to have turned out to be much more flexible and less restrictive with respect to individual firm behavior than was conventionally assumed. Under pressure from product and capital markets, many firms apparently learned to "stretch" the boundaries of their national regimes to fit their individual needs; consequently, as shown below in more detail, corporate structures and strategies became possible that would have been thought to require major changes in legal rules. As parallel national reforms responding to new international economic conditions allow firms to act in ways less determined by different legal systems and more by the identical demands of common international markets, they may give rise to identical responses regardless of national systems and thus contribute to cross-national convergence. At the same time, national systems granting firms more strategic freedom allow for more varied behavior within systems, thereby increasing the overall diversity of responses. This theme of convergence and divergence will return as our discussion proceeds.

European-level developments with respect to of workforce participation in labor law resemble those in company law. Since the early 1970s, various attempts followed each other to make different versions of the German system of works council representation obligatory for all European firms, or at least for all multinational firms. It was only in 1995 that a European Works Councils Directive was passed. It applies to multinational firms only and leaves most of the procedural and substantive details to negotiations at company level. National systems of worker representation, at both headquarters and subsidiaries, remain intact as the Directive merely combines them into an additional channel of representation for a company's European workforce as a whole. Typically, the legal and contractual rights of European Works Councils are weak in comparison to their national counterparts. Moreover, the way European Works Councils are structured and operate is largely determined by national practice in a company's country of origin. Basically, European Works Councils are no more than mechanisms of loose coupling of national systems of representation inside multinational companies, offering workforce representatives and management a border-crossing communication network which, however, remains centered on the company's headquarters and its home country.[2]

Summing up, instead of supranational harmonization European integration has increasingly developed and encouraged sometimes quite sophisticated arrangements of coordination between a variety of, essentially unchanged, national institutional settings. Within the emerging and, for early "integration theory", quite unexpected pluralism of regimes inside an integrated economy, firms have become important strategic actors as they have gained a capacity to create their own, idiosyncratic regime patchworks fitted to their individual needs. Moreover, it seems that the deep restructuring of the European economy in the 1990s was able to progress regardless of persistent differences in national company law and national industrial citizenship regimes. An important factor in this seems to have been a growing ability of multinational firms to construct their own, company-specific regimes of border-crossing corporate governance and industrial relations through freely negotiated contractual arrangements, like at Europipe, Airbus or Aventis (where German unions and German co-determination were included in the organization of companies partly or fully chartered in French law). Rather than legal harmonization, Europeanization of corporate governance and corporate organization seems above all to imply hybridization of national institutional legacies at the level of large firms, in an experimental, bottom-up fashion.

Also, and at the same time, Europeanization obviously offers firms ample opportunity for regime shopping and regime arbitrage. Here, too, large companies are the main and 
driving actors. A recent ruling of the European Court of Justice (Centros, March 9, 1999, C.21/297) seems to imply that firms may incorporate anywhere inside the European Union, wherever they find the local corporate law best suited to their interests and regardless of where they actually do business. If this is indeed the view of the Court, the "Delawarization" of European company law might become a reality as firms could easily switch their legal base to a country like the United Kingdom, where very few obligations and responsibilities exist for private companies. (Of course political considerations and the economic value of social peace with a company's home country workforce might and would be a mitigating factor, and countries may try to reassert their legal autonomy by amending the European treaty so as to make "regime shopping" more difficult.) Similarly, in the area of labor law, multinational European firms increasingly require their plants in different countries to compete with each other for investment and production, with workforce representatives in effect becoming business agents of local workforces that have to convince central management that their plant is more efficient than competing plants of the same company. In internal competition of this sort, cooperative labor relations at local level clearly are an asset that local management and local workforce representatives will be keen on cultivating.[3]

\section{Corporate Adjustment to Changing Product and Financial Markets}

Within their nationally fragmented institutional environment, European multinational firms have by and large successfully defended their position in a period of unprecedented economic change. Beginning in the 1980s, growing internationalization of product markets, together with a new technological dynamism, gave rise to intensified competition, which has forced fundamental changes in corporate organization. The simultaneous internationalization of financial systems has laid firms open to new pressures from capital markets that are driving further corporate restructuring (Amelung 1999, Zugehör 2000). In response to the global integration of formerly national financial systems, national states have reformed their financial market and corporate governance regimes, facilitating access of domestic firms to international finance as well as increasing the pressure for structural adjustment.

\subsection{Product Markets: Internationalization, Technological Change, and Intensified Competition}

International integration of product markets was in part a result of political decisions, such as the adoption by the European Union of its 1992 Internal Market program. More open markets were, however, also sought by firms in need to achieve sufficient scale to take advantage of the opportunities for growth associated with new technological advances, especially in the area of information technology. By abolishing what had remained of the protected home markets of the oligopolistic postwar era, international market integration not just enabled, but in effect constrained large European firms to expand internationally. By the end of the 1980s at the latest, the leading European corporations, organized in the European Business Roundtable, had come to the conclusion that even an integrated West European market was not large enough for the new challenges, and that a "Fortress Europe" with a European "industrial policy" supporting "European champions" was not an adequate response to the demands of the time. Nevertheless, in spite of the eventual accession of the European Union to the Uruguay Round agreement, and regardless of their increasingly global outlook, the majority of large European companies remain rooted in Europe, and indeed in their home countries, 
Growing competition, even in home markets, forced firms to seek larger scale and reduce costs, the latter resulting in increasing procurement of supplies and relocation of production abroad, mostly within Europe but also elsewhere. Movement of production to other countries was also motivated by the need to get closer to increasingly important foreign product markets with their different structures of demand; it was facilitated by new information technologies capable of controlling and coordinating, not just longdistance trade, but also far-flung international production systems. Internationalization of production made it possible for firms to shop for comparative advantage, in cost but also in infrastructure, skills and social institutions. A recent study of the 100 largest German firms found that firms that sell a large share of their production abroad also tend to employ a large and increasing share of their total workforce in countries other than their country of origin.[4]

In particular, corporate reorganization in the 1990s involved a continuing process of mergers and acquisitions; the privatization of what used to be large parts of countries' national infrastructures; and profound changes in firms' operational structures, both between companies and within.

- Already before 1992, large European firms embarked on an unprecedented wave of mergers and acquisitions which continued into the 1990s and for the time being reached its peak in 1999.[5] As firms try to grow as fast as possible into their expanded international markets, they rely on foreign acquisitions as internal growth may be too slow. Moreover, to finance investment in new technologies firms may need a minimum size they can best achieve by merging with others. Mergers and acquisitions also serve to reshuffle a firm's technological portfolio, in response to accelerating innovation and shorter product cycles, with technological advantage becoming a function in part of a creative corporate strategy of buying and selling subdivisions with different technological potentials. Finally, international mergers and acquisitions may increase a firm's market share in a global economy where concentration in most sectors is far lower than in most national economies.

- Privatization of national infrastructures, such as the telecommunications industry, took place partly in response to American pressures for the opening up of domestic markets. But it also reflected new technological possibilities that the old regimes were unable to exploit, as well as new consumer demands, especially by increasingly costconscious firms under growing international competition, that state authorities lacked the marketing skills and the dynamism to recognize and attend to. Moreover, adjustment to technological change often required investment of a scale for which public authorities were unable or unwilling to raise the necessary capital.[6] In most European countries, the European Union and its directives were instrumental for breaking domestic resistance, especially by public sector unions, against the wave of privatization that continued throughout the 1990s.

- While pursuing new international opportunities, many European firms went through a process of vertical disintegration. To cut overhead and spread risks, firms increasingly preferred buying over making of non-essential components, relying on close cooperation with subcontractors and system suppliers. Extended production networks involving large communities of small and medium-sized firms were built or reactivated as alternatives to both hierarchies and markets, partly imitating Japanese just-in-time systems and partly in rediscovery of older European traditions of regional 
cooperation, as embodied in "industrial districts" with their emphasis on shared resources and mutual trust.

- Throughout Europe, firms also restructured their internal organization in order to decentralize decision-making. Operational decentralization responds to needs associated with intensified domestic and international competition to cut the costs of managerial overhead. But it is also made necessary by more international production systems which, notwithstanding the capacity for centralized control offered by new information technologies, must leave enough discretion to local decision-makers to enable them to serve differentiated local demand. "Lean management" was the catchword of the 1990s. Its pursuit was accompanied by a new emphasis on the social integration of the firm on the one hand and the incorporation of market elements in corporate hierarchies on the other, the two being closely related to one another. The former, under headings such as "corporate culture" and "corporate identity", emphasized a newly discovered need for values and identities shared across hierarchical levels and territorial borders, to ensure that inevitably more autonomous decision-makers in their various locations acted on roughly the same general premises. The latter, in the form of increasingly frequent transformation of decision-making units into profit centers, or even of a spin-off of subdivisions to the stock market, replaced hierarchical discipline with material self-interest, so as to make close operational supervision redundant.

\subsection{Financial Markets: Internationalization and Pressures for "Shareholder Value"}

In recent years, European large firms have come under pressure to extend similar attention to shareholders, especially minority shareholders, as Anglo-American firms; this is reflected in the debate on "shareholder value" (Rappaport 1986; Prowse 1994) as well as in ongoing changes in European regimes of corporate governance. Anglo-American arms-length financial relations mediated through a developed capital market are increasingly beginning to invade and replace traditional European systems of national insider finance. In the process, the behavior of Continental-European companies is changing as they find themselves forced to address many of the issues emphasized by the standard corporate governance literature: e.g., how to ensure that minority shareholders are given reliable information; how to prevent "insider trading" at the expense of outsiders; and how to hold management accountable to the interests of minority investors.

The new significance of the stock market and the growing shareholder value orientation of Continental-European corporations are apparently not explained by changes in corporate finance (Achleitner and Bassen 2000, 12). Large firms were able in the 1990s to raise the capital they needed for international expansion internally and there seems to be no significant increase in equity finance, international or national, during the period.[7] Indeed among German firms at least, internationalization of product markets and production systems between the mid-1980s and mid-1990s was only weakly related to internationalization of credit and ownership.

Moreover, while cross-shareholding among national firms declined,[8] holders of large blocks of shares all in all held onto their position and certainly remain far more significant on the European Continent than in the U.S. and the UK. Consequently, although ownership did become more international throughout, the amount of capital held by dispersed owners did not rise dramatically. The obvious exception are the formerly public 
and now privatized sectors, like telecommunications. In many countries, the privatization of what used to be parts of the national infrastructure was seen as a strategic opportunity for governments to strengthen national capital markets, in part to increase their own return and in part because an internationally attractive capital market came to be perceived in the 1990s as a national asset essential for good economic performance. Privatization thus often went together with changes in regulatory regimes designed to making them more compatible with mass ownership of shares and offering middle-class households incentives to shift their savings to investment in the stock market.

The most important development outside the newly privatized sectors, which however soon affected these as well, was that dispersed shares where increasingly bought up by institutional investors, such as investment or pension funds, many of which were internationally based (OECD 1997; Jackson forthcoming).[9] In large German firms, more than half of the dispersed shares are now estimated to be in the hands of institutional owners; for example, at E.ON, the former VEBA, institutional owners hold about 75 per cent of total capital, at Bayer, 68 percent, and at Lufthansa, 59 per cent.There is as yet little research on the preferences and the behavior of institutional investors although most agree that to get them to buy their shares, firms must pay good dividends and, especially, grow faster in value than others. If they don't, institutional investors, not being particularly attached to any one firm, are more ready than traditional investors to sell their stock, making themselves heard, unlike the large blockholders that dominated European capital markets in the past, through the market rather than getting involved in management.

It seems to be the, by comparison, low patience of the emerging new institutional investors and the arms-length distance they maintain to management - their preference to remain outsiders to the firms in which they buy shares - which explain why the themes of the Anglo-American corporate governance discourse have become so prominent even in the core countries of Albert's "Rhine model" of capitalism (Albert 1993). Firms trying to persuade the new investors to buy their stock, or not to sell it, must offer them assurance against being taken advantage of by insiders. Given that the share price is the single most important information for outside investors, firms that compete for their favor must do what they can to raise it and keep it as high as possible. As firms begin to cater to market-oriented outsiders, traditional insiders are bound to lose influence, and with their capacity to play strategic insider games diminishing, not least due to changing stock market regulations, they, too, are likely to behave more like outsiders: comparing the value of their present investment with the potential yield of alternative investment, and getting ready to jump ship should the "shareholder value" of a given firm remain unsatisfactory over a longer period.

In the 1990s, pressures from shareholders and the need to attract footloose investors - or keep formerly patient investors from becoming footloose - seem to have become significant enough to make large European firms adopt practices in relation to their stock owners which, while not necessarily required in law, amounted to a significant emulation of Anglo-American practices of corporate governance. Among these are

- the voluntary adoption of American accounting standards, sometimes in conjunction with the listing of a firm's share at the New York Stock Exchange, to increase transparency for investors;

- the introduction of stock options for management, to align the economic interests of managers with the interests of investors in a high stock price. Often this meant a significant increase in managerial income, close to American or British levels; 
- the elimination of differential voting rights or voting restrictions, and generally a guarantee of equal rights for minority shareholders in the shareholder assembly;

- the creation of investor relations departments and the introduction of regular meetings with investors, especially institutional investors, and analysts, to provide detailed information about the firm and its business prospects.

Also, to become attractive to more market-minded investors, many European firms introduced numerical profitability targets, for the entire company or by subdivisions. Such targets are publicly stated, implying that if they are not met the respective divisions will be restructured or sold off. They are also internally used to support managerial efforts to improve efficiency and competitiveness. For similar purposes, firms may take individual subdivisions public,[10] reinforcing replacing the hierarchical authority of corporate management with the discipline of the stock market.[11]

Moreover, as highly diversified firms whose performance is difficult to assess for outside investors tend to find their share price reduced by what analysts call a "conglomerate discount", they are increasingly selling off parts of their business and concentrate on a limited number of core activities (Amelung 1999; Lang and Stulz 1994; Zugehör 2000). German conglomerates that are exposed to the capital market are de-diversifying, whereas conglomerates that are not traded on the stock market tend to retain their traditional structure (Zugehör 2000).[12] Capital market pressure for "shareholder value" thus seems to drive further restructuring, adding to the effect of more competitive product markets. De-diversification implies a fundamental reversal in corporate organization away from the diversification philosophy of the 1980s with its emphasis on a balanced internal distribution of profits and losses. In effect, it transfers the decision on the structure of investment portfolios from corporate management to the individual shareholder or his financial agents in the "financial services industry".

The trend toward market finance was reinforced by independent developments on the supply side of the capital market. Even faster than in industry internationalization proceeded in the financial sector. European banks trying to establish themselves in the emerging international financial sector soon found that the profitability of American-style investment banking exceeded that of European-style credit allocation under a traditional house bank system. To achieve growth and profit rates comparable to those of their international competitors, European banks such as Deutsche Bank gradually withdrew from their traditional role as "house banks" of national firms and became unwilling to function as infrastructures of national economies and national industrial policies. Instead they increasingly behaved like conventional businesses maximizing their profit in an integrated international "financial services industry" in which they had to compete with American and British investment banks.

The ultimate means for outside investors to get the attention of corporate management is, of course, the threat of a hostile takeover. Where hostile takeovers are legally or factually impossible, outsiders may feel less certain that they will be treated fairly, and may therefore be unwilling to invest their capital. Responding to this, a market for corporate control is slowly developing in Europe, even in countries where the legal framework of corporate governance has so far remained unchanged. The trend towards more frequent hostile takeovers [13] is reinforced by the changing business strategies of large banks with their desire to make the same profits from investment banking in their domestic markets as do their Anglo-American competitors. Banks have also been foremost among the forces that have lobbied national governments to remove political, institutional or legal obstacles to hostile takeovers and thereby open up new business opportunities for the 
The three major German takeover cases of the 1990s follow a telling trajectory. While the attempt by Pirelli to take over Continental, which lasted from 1990 to 1993, was prevented by a coalition of government and cross-shareholding German firms (the socalled "Deutschland-AG"), the attempted take-over of Thyssen by Krupp in 1997 was renegotiated into a merger after union protests, and the Vodafone bid for Mannesmann in 1999-2000 was handled by all involved, including the union, more or less as business as usual, under careful avoidance of ideological rhetoric. Impending legislation on tax reform in Germany will vastly reduce, if not eliminate, capital gains taxes for banks and corporations selling their stock holdings. This is likely to be the beginning of the end of the German pattern of bank ownership of stock and of cross-shareholding, which was difficult to penetrate from the outside and represented a major obstacle to hostile takeovers (Höpner 2000b; 2000c).

As hostile takeovers become more possible, firms are forced to pay more attention to their increasingly less loyal shareholders - new as well as old ones - who may react to declining share prices by exiting via a more liquid capital market. Since low share prices may in turn attract hostile takeovers, large firms have very strong incentives to do what they can to raise the value of their stock, among other things by de-diversifying their operations in anticipation of what a new management would do after a successful takeover. High share prices, as generated by a management policy of "shareholder value", may also be essential for fast international expansion as it may enable firms to use their own shares as a currency for mergers and acquisitions (Bühner 1997; Rappaport and Sirower 2000).[14]

\subsection{National States: Changes in Corporate Governance and Financial Regimes}

A number of European countries have in recent years changed their company laws and capital market regulations, both to improve the access of national firms to outsider capital, especially foreign capital, and strengthen the competitive position of the national financial sector in the emerging global market for financial services. With respect to corporate governance, recent national legislation, among other things, raised the disclosure requirements for firms, extended the rights of minority shareholders, liberalized the use of stock options, made it possible for firms to apply international accounting standards or to buy back their shares, and removed obstacles to hostile takeovers.[15] Also, measures were taken to prevent insider trading at the stock exchange and generally make dealings in financial markets more transparent.

Responding to international market pressures that were felt by all Continental-European countries alike, national reforms of corporate governance and financial regulation tended to move in the same direction even without explicit international coordination or a binding mandate from the European Union. The resulting cross-national convergence was probably the most important reason why a unified European company law seems to have become less urgent in the 1990s. (European Union influence was more important in the reform of financial markets, similar to the 1980s when the Union had mandated its member states to open up large segments of their public infrastructure to international competition and privatization.) Parallel national reforms had the advantage that they could remain limited to corporate governance in a narrow sense avoiding the issue of co- 
determination that had so effectively blocked the progress of European company law. National industrial citizenship regimes thus remained largely unchanged in the 1990s. As a result, with company law beginning to converge on a more market-driven pattern, industrial citizenship became the main source of diversity in corporate organization, both within Europe and between Continental European countries and the Anglo-American world.

National reforms of European corporate governance regimes were frequently preceded by changes in the practice of leading companies, and to this extent they only ratified and generalized what was already under way. In adjusting to the new capital market pressures, for example by furnishing improved information to minority shareholders, firms in different countries adopted similar practices, regardless of differences between their national regimes ("functional convergence", Gilson 2000). At the same time, company practice within national regimes seems to have become more different, also over time; German responses to hostile takeovers, from Continental to Mannesmann, changed fundamentally in spite of a basically unchanged legal environment.[16] Both identical behavior in different systems and different behavior in identical systems indicate a declining capacity of national regimes in an international economy to control domestic firms. They also signify the emergence of large firms as increasingly independent strategic actors with a growing capacity, in a more competitive and uncertain environment, to respond to challenges autonomously and in a way that fits their individual circumstances best.

\section{Challenges to Industrial Citizenship and Public Accountability}

European "stakeholder" firms, as has been pointed out, are embedded in national regimes of industrial citizenship and public accountability, more so than their Anglo-American counterparts that are regarded by the legal systems of their home countries as private the affair of their shareholders. The following section will explore how the pressures for corporate restructuring that have emanated from changed international product and financial markets, and the responses of large firms to these, are affecting the social institutions designed to hold large European firms accountable to their workers and the public interest. Most European firms seem up to now to have been able to respond successfully to the new economic challenges, in spite of institutions such as codetermination and the welfare state and without having to turn against them. In fact, firms sometimes seem to have managed to make a virtue out of necessity by turning their institutionalized social responsibilities into sources of comparative advantage. At the same time, the national institutions that sustain the stakeholder model of the firm have also changed, if only in that firms seem to have gained greater freedom with respect to their choice of structure and strategy. Even where legal rules have remained the same, this amounts in an important sense to deregulation. The central question seems to be whether the social institutions that support stakeholder capitalism, to the extent that they are not pushed aside or made irrelevant by the pressure of product and financial markets, will allow European firms to develop an economically sustainable answer to the new economic conditions, perhaps by helping them develop specific productive strengths and comparative advantages matched to the demands of particular categories of customers and capital givers. 
Unlike corporate governance, there has been no major national legislation on work-force participation since the 1970s. In most Continental-European countries, firms continue to have to live with strong unions and more or less well-institutionalized systems of workforce information, consultation or even co-decision making. While initial attempts to unify such systems at European level have failed, so have hopes that Europeanization would make them disappear. Indeed in most countries ideological conflicts on "industrial democracy" have abated, even in Germany where workforce participation rights are comparatively strong, and the European Works Councils Directive once passed was implemented without much debate even in countries not used to formal institutions of workplace representation.

Rather than lobbying national governments for retrenchment of traditional regimes of workforce participation, European large firms on the whole seem to prefer to make a virtue out of necessity by using extant institutions of workforce participation as infrastructures of labor-management cooperation in pursuit of consensual adjustment to the new competitive conditions. Indeed where obligatory national participation regimes are missing, firms sometimes voluntarily set up institutional arrangements for joint information and consultation, often prodded by their experience with the new European works councils. Moreover, some firms try to capitalize on the institutional legacy of industrial citizenship and seek comparative advantage over their Anglo-American competition through economic strategies that emphasize human resources and human capital and depend for their success on the good will of the workforce and the social integration of the firm as a competitive community. In support of such strategies, efforts are made to turn the institutions of industrial citizenship, which originally reflected antagonism between capital and labor, into a substructure of social partnership and "comanagement".

Workforce participation in management has been differently modeled theoretically. For theories of property rights, workforce participation results in an inefficient allocation of decision rights to actors whose income from the enterprise is contractually fixed, as opposed to being a residual whose size depends on the efficiency of the firm. Also, codetermination is seen as making it unduly difficult for owners, or "principals", to prevent their managerial "agents" from catering to interests other than those of owners; it may thus exacerbate the principal-agent problem of the large corporation. Similarly, in a price-theoretic view, co-determination is likely to cause a distortion of relative factor prices, forcing the firm to use more capital than would be economically efficient.

Theories that try to model the economic effects of cooperation, by comparison, emphasize that firms depend on investment, not just from capital owners but also from workers, extending the concept of a firm's installed capital to include the workplace-specific skills of workers and their general willingness to cooperate with management (their "good will"). By strengthening the trust of workers in management, participation in enterprise decision-making may then increase worker willingness to invest in their ongoing employment relationship, thereby expanding the "capital" available to the firm. As a consequence, the productivity of the enterprise may rise, creating the condition for joint realization of cooperation rents.

Similarly, theories of participation emphasize the economic benefits of a stable workforce with low turnover and correspondingly high social integration. By granting employees a right to "voice" their concerns, participation enables them to stay on and not "exit" from 
the firm. This lowers a firm's search and transaction costs in the labor market and gives it the confidence that its investment in the generation of firm-specific skills will be redeemed. Rights to participation also give workers reason to expect fair treatment from management, which encourages them to supply information to management that might be crucial for improving efficiency; such rights are therefore conducive to "informationintensive" management and work organization. Mutual confidence rooted in rights of representation further supports a more flexible organization of work, as it makes a priori specification of mutual rights and responsibilities less necessary; it thus lowers transaction costs, not just in the external labor market, but also between hierarchical levels.

Which of the different economic effects of participation will take precedence in a given case may be impossible to specify a priori. Indications are, however, that the European institutional heritage of industrial citizenship has up to now not in a major way obstructed adjustment of European firms to the new economic conditions, and may sometimes to the contrary have been an economic asset:

- Recent evidence from Germany suggests at a minimum that even strongly institutionalized rights of industrial citizenship need not stand in the way of high competitive performance, even in a period of rapid economic internationalization (3.1.1).

- While conflicts between management and labor over industrial adjustment, especially to more demanding capital markets, cannot be ruled out, initial research indicates that firms can devise structures and strategies that are acceptable to both sides (3.1.2).

- In fact product and capital markets seem to offer firms constrained as well as supported by regimes of industrial citizenship strategic niches that allow them to satisfy the demands of their stakeholders without having to accept competitive disadvantages (3.1.3).

- Although legal changes in workforce participation regimes were rare in recent years, in practice firms and workforce representatives have often informally modified existing arrangements to fit the specific economic, technological and organizational circumstances of individual companies. Customized solutions of this sort increase the variety within national systems while sometimes giving rise to similarities across national borders (3.1.4).

- While today's regimes of industrial citizenship, with some modification, have not prevented and sometimes helped firms adjusting to the new market pressures, it remains to be seen whether they will allow fundamental changes in the organization of the employment relationship even if these were required for higher productivity and more rapid innovation (3.1.5).

\subsubsection{The Report of the German Co-Determination Commission}

In 1998, after two years of work, a semi-official high-level commission set up by two major foundations and composed of representatives of unions, business, the government and the judiciary, as well as of independent scholars, delivered a report on the condition and the economic effects of the German co-determination system, some twenty years after the last major legislation on the subject (Kommission Mitbestimmung 1998).[17] In its economic part, the report emphasized the high prosperity of postwar Germany, and 
especially the lasting success of its industrial sector in world markets, which was due to high productivity compensating for high wages. The report noted that it is in the exposed sectors of the German economy, whose export surplus reached a new record in 2000, that co-determination through works councils and on company supervisory boards is especially firmly established. It further pointed out that due to the high international competitiveness of German industry, the de-industrialization of the German economy has proceeded more slowly than in comparable countries; that industrial employment is as a consequence higher in Germany than in all other large countries; and that the employment deficit of the German economy is located, not in its exposed but in its sheltered sectors, especially in low productivity services where co-determination hardly exists.

Slow de-industrialization, according to the report, does not indicate technological backwardness or lack of structural dynamism. Investment rates are higher in Germany than in the U.S. and the UK, and the capital stock is larger (see also de Jong 1997). Successful restructuring is reflected in strong growth in production-related services; in a dominant international position of sectors using advanced technology, such as industrial engineering; in rapid organizational change especially in the 1990s; and in the accelerated internationalization of German companies. The report mentions an increasing use of foreign supplies by German manufacturers and draws attention to the fact that DaimlerBenz, Volkswagen and Siemens at the time already employed more than 60 percent of their total workforce outside Germany. Had it appeared a few weeks later, it could also have commented on the Daimler-Chrysler merger, especially the fact that the new company decided to remain incorporated in German law, continuing to subject itself to co-determination, although it could easily have moved its seat to the U.S. to escape the German system had it perceived it as economically burdensome.

The report did not undertake to establish a direct causal connection between codetermination and the prosperity of the German economy. It pointed out, however, that strong rights of workforces to information, consultation and co-decision making had obviously not interfered with international competitiveness. It also suggested that codetermination might have contributed to the evolution of a specific mode of production in Germany that emphasizes the cultivation of human resources and of dedicated, long-term employed workforces. The report furthermore described in detail the experience of the 1990s when most German firms responded to the dual challenge of globalization and German unification by a policy of "cooperative modernization" negotiated with workforce representatives and jointly implemented in spite of sometimes considerable pain caused to workforces.

\subsubsection{Competitiveness and Shareholder Value: Strains on Industrial Citizenship and Labor-Management Cooperation?}

While struggling to adjust to more competitive product markets and an increasingly marketized capital nexus, large European firms strive to protect traditionally cooperative relations with their workforces, in order to maintain social peace at the workplace which firms regard as an important competitive asset. While balancing the demands of customers and investors on the one hand with those of workforces on the other is not without difficulty, it seems not to be impossible either. Nevertheless, one of the central questions for corporate organization in Europe is whether the disappearance of more or less protected national product markets and the growing role of anonymous market mechanisms in corporate relations with capital must result in a more market-driven, less negotiated and regulated, and therefore more conflictual relationship with labor - or, 
alternatively, whether traditional systems of industrial citizenship, originally matched to protected markets and negotiated finance, can be used or rebuilt to satisfy new capital and product market requirements without undermining the cooperation between management and labor that they have in the past made possible.

\subsubsection{Industrial Citizenship and Competitiveness}

Concerning organizational restructuring to defend and restore competitiveness in product markets, a number of trends have become visible in recent years that may be summarized as follows:

- Relocation of production abroad was more often than might have been expected accepted by home country workforces and their representatives, provided that it could be shown to contribute to the competitiveness of the company as a whole, and thereby to the long-term protection of domestic core employment.[18]

- Often movement of production to other countries or outsourcing of parts could be avoided due to productivity-enhancing concessions by domestic workforces.[19] German works councils joined management in the 1990s in a search for organizational and other improvements to allow firms to continue production in-house and in Germany. In the report of the co-determination commission of 1998, this was referred to as "co-management".

- Competitive benchmarking between plants of the same company, often across national borders, is not necessarily resisted by workforces. Workforce representatives sometimes act as "business agents" of their constituents in that they work to put together competitive packages to be offered to central management deciding on the allocation of production or new investment. Alliances between worker representatives at plant level and local management lobbying headquarters on behalf of a particular production site seem to be frequent. Where workforces are well-organized, for example at Volkswagen, workers seem to stand a particularly good chance of coming up with convincing business plans, in internal competition for work and investment just as in competition with suppliers or potential suppliers.[20]

- Not infrequently, companies negotiate with their workforces comprehensive restructuring packages designed to enhance the competitiveness of the company as a whole or of individual plants. In Germany, about half of the 100 largest companies have negotiated at least one such "location agreement" (Standortvereinbarung) with their works council (Rehder 2000). One third of the agreements entail an understanding on the amount of investment the firm will make in a given location, in exchange for workforce concessions increasing productivity and lowering production costs. Agreements of this sort activate organizational productivity reserves, and thereby make it possible for management to give assurances on future levels of investment and employment. The vast majority of such understandings in large firms are not in breach of sectoral industrial agreements with trade unions, and often the unions concerned take part in the negotiations. Even where this is not the case, they usually are indirectly involved as most works councils are not willing to sign an agreement that has not been at least tacitly approved by the union. In fact some industrial agreements now explicitly contain "opening clauses" that offer firms and workplace representatives flexibility for location agreements, within a framework defined by industry-wide collective bargaining (Bispinck 1997). 
- Where restructuring requires cuts in employment, which it did especially in the first half of the 1990s, managements seek agreement with worker representatives by trying to avoid forced and involuntary redundancies. Here as elsewhere, extensive access of worker representatives to information is essential. Where internal redeployment or natural attrition are not sufficient to bring about a necessary employment reduction, companies and workforces often protect their cooperative relations by jointly calling upon the welfare state to take care of those whose jobs have to be eliminated. A major instrument in many Continental-European countries for management and workforce representatives to preserve social peace at the workplace, while together rebuilding the workforce to make it more productive, is early retirement. In this way, some of the costs of restructuring are externalized to the public. Also, governments have been lobbied jointly by employers and unions to subsidize working time cuts, or to devise public retraining programs of redundant workers under which net wages were replaced out of unemployment insurance or other public funds.

- Large firms also managed to make their use of labor more contingent on product demand, and thereby turn into what in Germany is called "breathing enterprises", without incurring much resistance from their workforces. Where flexible working time arrangements did not suffice, firms have found ways, again often in negotiations with workforce representatives, to discriminate between a safely employed core workforce and a marginal workforce to be expanded and reduced in response to changing demand. While European unions normally oppose a dual employment regime, at enterprise level they were often willing to safeguard the interests of the unionized core workforce by allowing the firm to rely on the external labor market for temporary adjustment of the labor input. In effect, this tends to exclude parts of the workforce from the full rights of industrial citizenship. Among the more inventive methods devised in this context is an increasing use of temporary workers employed by temporary work agencies that are themselves unionized.

\subsubsection{Industrial Citizenship and Shareholder Value}

Concerning relations with investors, growing attention of firms to "shareholder value" is often thought to undermine cooperative labor relations, and eventually jeopardize European institutions of industrial citizenship, by making firms replace negotiated with market-driven labor relations. Also, the ongoing evolution of a "market for control" for firms seems likely to have adverse distributional consequences for labor. This is because takeovers, as well as the measures taken in defense against them, are bound to increase share prices compared to the value of capital installed, forcing companies to devote a larger share of their value added to dividend payments, at the expense of the shares of labor and of retained earnings.[21]

Other elements of shareholder value, however, seem to be quite compatible with worker interests and cooperative labor relations, or can be made compatible with them:

- To the extent that outsider capital and new capital market and corporate governance regulations force companies to publish more detailed and accurate information on their economic condition, this also benefits worker representatives. In fact, even in Germany where obligations of firms to share information with their workforces are comparatively strict, unions and worker directors on supervisory boards have welcomed firms following U.S. reporting standards, and have supported legislation 
raising transparency requirements for joint-stock companies.

- It is interesting to note that in the current debate on a new German takeover code, unions refrain from pressing for extended possibilities for target firms to defend themselves against takeover bids (see Köstler 2000). This indicates that unions and works councils expect to be able to defend their position even under new "rules of the game" in capital markets.[22]

- Although the introduction of management stock options in Continental-European corperate governance regimes will very likely increase the income difference between workers and managers - which may cause discontent in a country like Germany where management pay was traditionally and still is low compared to the U.S. or Britain - it has in a number of cases been made acceptable to workforces by simultaneous introduction of employee stock ownership plans.[23] Depending on how these are designed, they may also lay to rest some of the distributional concerns with regard to the relative size of the labor and capital shares in a firm's value-added as they ensure that part of the relative increase in the share of capital owners goes to employees.

- Measures taken by management to raise the share price to insure against hostile takeovers often meet with the support of workforce representatives. This includes even de-diversification, in the form of selling off parts of the company that are unrelated to its core business. In Germany there are cases in which works councils and worker directors were among the first to urge the management of a firm to restructure in order to increase stock market value. Significant stock ownership by employees may make joint labor-management efforts in pursuit of higher stock prices even more likely. Especially where share ownership is widely dispersed, employee ownership, which may involve one to three percent of outstanding stock, may in itself provide insurance against takeover.[24]

- Research on large German firms suggests that de-diversification may be supported even by workers whose divisions are sold off in the course of strategic concentration on core business. Within diversified companies, some divisions may be used as cash cows to generate funds for investment in other divisions. In the case of Mannesmann, it seemed that workers and worker representatives in the automotive and other sections were content being sold off as they had for years been starved of investment in favor of the fast-growing telecommunications division. In fact union and works councils made it one of their central demands during the takeover negotiations that the automotive section should be taken public to be able to raise its own capital (which in the end was not done as the division was sold to Bosch; Höpner and Jackson 2000).

- The Mannesmann case is instructive also in that, after some hesitation, union and works councils accepted the takeover procedure as legitimate, and limited themselves to bargaining with the old and new management for reassurances on their own role and the company's future policies. In the end the union - whose national president sat on the Mannesmann supervisory board as an outside worker representative - expressed its satisfaction with the understandings that were reached. Also, the works council saw no reason to refuse the new management the sort of cooperation that it had offered to its predecessors. Unlike what might have been expected, the Mannesmann case is far from being seen by the unions as a threat to their position or to the German system of "social partnership", and no steps have been taken by the union or the socialdemocratic government to rule out similar takeovers in the future.[25] 


\subsubsection{Product and Capital Market Niches for Stakeholder Firms?}

Institutionalized workforce participation was found to foreclose price-competitive economic strategies of firms while encouraging and supporting quality-competitive ones (Streeck 1991). Different regimes of corporate governance appear to be associated with different productive strengths and strategic predispositions of firms, making firms that are subject to a given regime likely to be more successful in some market segments than in others.[26] As strong workforce representatives can force firms to provide for long-term employment and pay high wages, they in effect constrain them to invest in skill upgrading. Also, legally guaranteed rights to information and co-decision-making, while they impose costs on firms, tend to generate trust of workers in the fairness of management; this, in turn, gives rise to worker identification with the firm and high motivation at the workplace. Both skills and motivation support worker attention to quality and productivity, which creates an incentive for firms to devise competitive strategies that rely on these for comparative advantage. Trust also makes it possible for workers to tolerate high profits as credible assurance can be given that a large share is invested in research and development in pursuit a high-skill, high-wage business strategy. Managements of stakeholder firms confronting strong workforce representatives that insist on steady employment, high wages, and skilled work thus face constraints as well as opportunities to seek out international market niches for quality-competitive customized goods in which they can make the most of worker skills and trust as competitive assets.

Management attention to shareholder value, as imposed on firms by the new capital markets, is sometimes thought to require firms to adopt a short-term perspective that would make it impossible for them to invest in the productive capacities required for diversified quality production. Shareholder value would thus turn social partnership from a potential strategic asset into an expensive liability that firms would have to cut. However, while capital market pressures have been found to make German conglomerates exposed to them de-diversify, they do not seem to interfere with long-term investment in research and development or in human resources. Initial statistical analyses of the investment behavior of the largest German firms show capital market pressure and shareholder value orientation of management to have no negative influence on investments that are typically taken as indicative of a long-term perspective and that are particularly dear to representatives of the workforce (Zugehör 2000). To the extent that workforces take an interest in the firm developing a long-term business perspective, that interest does not seem to be in conflict with the interests of stock owners, even if these are now mediated by an anonymous stock market and interpreted in terms of "shareholder value". While worker representatives may have to accept de-diversification to protect the firm from being punished by a "conglomerate discount" in the stock market, there is still space for them to influence the firm's investment strategies in line with the interests of their constituents, without fear of retribution from stockholders.

Other evidence that there is no "co-determination discount" in stock markets is found in interviews with stock market analysts and investor relations officials of large German companies. In meetings with executives, analysts never seem to ask questions on the role and strength of co-determination bodies; instead they are exclusively concerned with a firm's present performance and its longer-term prospects. Investment in technology and human resources, of the kind that German works councils typically demand, does not seem to be held against companies by "the markets", even under standards of strict shareholder value, if they can be expected to benefit shareholders in the future.[27] 
Moreover, the demands of stockholders with respect to the performance of the firms in which they invest need not be assumed to be homogeneous, giving firms a strategic capacity, not only in choosing the type of product market in which they want to compete, but also in selecting investors whose preferences match the firm's specific performance profile. Firms that on account of their internal structure, in particular of a stakeholder-type corporate governance regime, are predisposed to excel in activities that require a longterm investment perspective and a skilled and motivated core workforce, may attract investors looking for a long-term stable return. Pronounced differences in preference seem to exist in particular between institutional investors and there are indications that European firms actively seek out investment funds whose strategy is compatible with theirs, so as to insure themselves against excessive volatility in their capital markets and gain enough time for their projects to mature. In effect, this would amount to the creation of a niche in international capital markets for firms that perform best when pursuing a long-term business perspective, in parallel to the market niche for diversified quality production that socially embedded firms with a demanding industrial relations regime have found and developed in international product markets.

\subsubsection{From Legal Prescription to Voluntary Negotiation: Increasing Variety Within National Regimes}

Since workforce representation regimes remained by and large unchanged in the 1980s and 1990s, national diversity between multinational firms today resides mainly in different arrangements of industrial citizenship, rather than in corporate law in a narrow sense. At the same time, as the management of the employment nexus was rediscovered as an important strategic parameter for firms, national workplace participation regimes underwent numerous adjustments that were, however, made at the firm level within and on top of extant legal rules, driven by a desire to build or defend competitive advantage. In Continental-European firms such adjustments, which may be viewed as having substituted for legislative reforms, were made mostly through negotiations between management and workforce representatives. In the process traditional systems of industrial citizenship and industrial relations were re-oriented from passive entitlements of workers to the joint pursuit of cooperation rents. As firms developed new forms of institutionalized labor-management cooperation, adding to and modifying legally prescribed arrangements, differences between firms within national systems increased while practices of firms from different countries sometimes converged regardless of the different legal regimes in their home countries.

The new relationship between legal and voluntary arrangements for workforce participation, and the growing attention of large firms to internal institution-building, became particularly visible in the implementation of the European Works Council Directive. The Directive allows firms, together with their workforces, wide discretion as to its implementation. It is true that the obligatory requirements of the Directive are not demanding and remain far behind German or Dutch standards. But it is also true that many large firms, including some British firms which due to the British "opt-out" were originally not covered by the Directive, used the creation of a European works council as an opportunity to establish for the first time a direct channel of communication to the workforces of their plants in other European countries, that is, as a device to advance social integration in a multinational organizational setting. Research indicates that only in rare cases did firms agree to formal workforce participation rights exceeding the low minimum standard prescribed by the Directive. It also indicates, however, that a surprising number of firms take the meetings of their European works councils seriously; 
send high-level management representatives to be available to the representatives of the workforce; and generally express satisfaction with the European works council as an instrument of internal communication and social integration beyond national boundaries.

Similar tendencies were observed by the German co-determination commission. On the basis of evidence provided by works councilors and management from a number of large firms, the commission concluded that in the practice of co-determination, firms often inform and consult their works councils above and beyond legal requirements, even though these are already high in Germany. The Commission also found a wide variety of arrangements that had been consensually set up to adapt co-determination to the situation of individual companies and workplaces undergoing fast change. In a number of cases, legally prescribed procedures had entirely fallen in disuse and had been replaced with improvised structures more suited to changed circumstances. Nevertheless, the commission emphasized that the legal basis of co-determination, while it had lost in prescriptive power with respect to everyday details, continued to be important as it took major dimensions of the relationship between management and labor out of direct contention. In this way, it provided each side with assurance against possible opportunism of the other, offering a last resort in cases when one side abused the other's trust within voluntary arrangements. In other words, the growth of voluntary cooperation, in the view of the commission, did not make the legal framework of industrial citizenship redundant; without the underlying, legally enforceable obligation to cooperate in good faith, the informal elaborations and amendments that had been developed under the pressure of more demanding markets would very likely have been less stable and effective.

Also interesting to note is the fact that evasion of national systems of workforce participation, in particular by moving the seat of companies to countries with weaker industrial citizenship rights, has not yet occurred. The example of DaimlerChrysler has already been noted. So has that of Aventis, a merged Franco-German company that, while incorporated in French law, made provisions in its charter for workforce participation that satisfied unions and works councils at its German component, the former Hoechst AG. Generally the practice of writing participation rights into the charters of new multinational firms, in the absence of supranational law and where national legal systems do not fit, seems to be becoming more frequent. Contractualization of participation regimes, as in the case of European Works Councils, coincides with tendencies towards customization of labor-management cooperation at company or workplace level. Obviously the fact that no major case of evasion of strong workforce participation systems has as yet occurred does not mean that none will happen in the future. Also, more research would be required to determine what concessions national unions and works councils had to make for their institutional influence to be protected in newly created multinational European companies. Nevertheless, most large European firms do not presently find it worthwhile to risk a deterioration of their labor relations by attempting to eliminate workforce rights to information and consultation. Instead firms actively try to use traditional national participation regimes as a foundation on which to build stable cooperative relations between management and labor at company level.

\subsubsection{Industrial Citizenship as a Limiting Condition for Organizational Modernization?}

European regimes of industrial citizenship originated in the world of the large bureaucratic firm. They were and continue to be based in long-term employment in 
internal labor markets, which gives rise to identification of workers with the employing organization, and to a preference for voice over exit as a way of expressing discontent. They also presuppose an employment relationship that distinguishes sharply between employer and employee, the latter being given security of employment and income in return for broad acceptance of the former's "right to manage". Modern work organization has in part de-bureaucratized the role of employees, assigning them more responsibility for the quality and profitability of their work and expecting them to internalize a range of managerial tasks and identify with the "corporate culture" and the objectives of the firm. In Europe this has mostly been supported by workforce representatives under existing participation regimes, as have more contingent pay, including stock ownership of workers, increasing contributions of employees to the costs of their training, and generally the insertion of more entrepreneurial elements in the work roles of operators, for example through the introduction of profit centers and internal competition between plants for employment and investment.

While on the whole going along with the modernization of the employment relationship, unions and workforce representatives have, however, always insisted that the new elements of the organization of work be incorporated in the basic framework of dependent long-term employment. Where they conceded a more dualistic employment regime that distinguishes between a safely employed core and a contingent marginal workforce, this was done, not to abandon, but rather to defend their fundamental preference for a bureaucratic employment model. Modern unions and works councils, having attached themselves to the structure of the large corporation and the interest-homogenizing bureaucratic employment relationship, find it difficult to organize and integrate the heterogeneous interests of workers in subcontracting, casual employment and selfemployment regimes. If it was true that in present conditions, high economic performance and leading-edge innovation ideally require more fluid employment, with fast turnover of specialists and outsourcing on a large scale, and with a wide variety of employment and subcontracting regimes shading into each other - in other words, a breaking-up of the long-term employment relationship and of the bureaucratic organization of the firm, in response to presumably declining productivity of long-term association between employer and employee - European industrial citizenship may turn into a limiting condition for organizational modernization.

There is always more than one way to skin a cat. It is an open question whether modernization of work organization and innovation regimes can be accommodated, with the cooperation of unions and works councils, in a revised, de-bureaucratized, more heterogeneous employment relationship, and whether long-term employment with the same employer can still be put to economic advantage. Certainly Continental-European firms, unlike Anglo-American ones, will explore the economic and organizational potential of the waged employment relationship to the last, as they probably have no other choice given the institutional framework under which they operate. The outcome of this will very much determine the economic future of the European model of corporate organization, or indeed of the European "social model". Indications are that at least at the level of top management, long-term employment has been losing some of its economic advantages even in European firms. Research on the chief executive officers of 40 large German firms shows unprecedented turnover in the 1990s; a significant decline in CEOs' length of tenure, as well as in the time of their association with the firm that they run; and growing professionalization in that the number of CEOs without an academic degree and with a career from the shopfloor to the top, usually in the same company, has sharply declined.[28] It remains to be seen whether these tendencies, which seem to represent a major break with traditional practice, respond to general economic pressures that will 
make them trickle down to lower ranks of the hierarchy, in particular those of the nonmanagerial workforce represented by unions and works councils.

\subsection{Corporate Accountability in an International Economy}

Traditional European conceptions of the corporation include a notion of a legitimate public interest in the firm existing alongside and in some cases superseding the interest of shareholders.[29] What that interest may be now that the time of inside ownership and owner management has ended, and how firms may be held accountable to such interest in an international economy is the most fundamental issue behind current discussions on a "stakeholder firm" - discussions that lack grossly in clarity and precision of both questions and answers.

As an empirical matter, we observe a growing variety of corporate structures and strategies designed to satisfy the - potentially conflicting - demands on firms of capital markets and industrial relations institutions, reflecting an increase in corporate autonomy in relation to national financial and industrial citizenship regimes, even on the European Continent. Growing variety between firms subject to the same national regime indicates that national public policy is losing its grip on corporate organization and behavior, with international private markets increasingly taking the place of public legislation as the main mechanism of corporate discipline and accountability. One consequence seems to be that what used to be industrial citizenship is turning from a publicly guaranteed right of workers, created to hold firms accountable not just to their workers but to "the public interest", into an economically expedient internal arrangement strategically chosen by firms in pursuit of improved productivity and competitiveness.

As large firms learn to treat their internal social integration as an important parameter of their competitive structure and strategy - as, in other words, they turn into "institutional firms" (Crouch and Streeck 1997) - new lines of division are beginning to emerge between their workforces and other workers that may be difficult to reconcile with Continental-European notions of equal industrial citizenship rights for all regardless of place of employment. Equally critical from a public policy perspective are dualistic tendencies inside the corporate employment system where safely employed core workforces, which increasingly turn into both co-managers and co-owners, are separated by a growing gap from a marginal workforce on which corporations rely for flexibility, without offering them much of a chance to advance into the core. Paradoxically, consensual social closure of corporate internal labor markets may utilize traditional European institutions of industrial citizenship as a vehicle, transforming them gradually from a universal right into a particularistic privilege, and thereby effectively privatizing what was intended to be a public institution.

Closed institutional firms are difficult to govern from the outside. They also tend to be quite adept at externalizing some of the costs of their internal integration to society-atlarge. An important example is the use of the old-age pension system in numerous Continental-European countries to slim down workforces by placing older workers on early retirement. Not only does this increase a firm's economic competitiveness. It also safeguards its internal social peace at the workplace in difficult restructuring periods as workforce representatives are usually willing to agree to employment cuts if those concerned are allowed to retire on generous terms. Indeed unions and works councils typically join managements in lobbying the government to provide for extensive opportunities for early retirement of workers made redundant by their employers. As the 
experience of several countries shows, the costs of private consensus-building of this sort to the public purse and, as a result of subsequent increases in non-wage labor costs, to the level of employment and economic activity may be significant.

The externalization to society of the costs of corporate social integration through early retirement schemes is one factor among others contributing to a growing gap between the increasing demands strategically more autonomous large firms make on public policy, and the declining contributions they can be obliged to make to it. Large multinational firms can easily shift their taxable profits from one country to another, enabling them to choose the country where they will let themselves be held responsible for contributing their share to the maintenance of infrastructure and social cohesion beyond corporate boundaries.

Among other things, this results in strong pressures on national governments to lower corporate taxes or even rely exclusively on income and consumption taxes for financing public goods - at the risk of social peace, if not at the workplace, but in the polity-atlarge.

The issue is considerably complicated by the increasingly international character of large firms. More self-confident firms press governments for liberalization of national capital market and industrial relations regimes, with the inevitable consequence of cross-national convergence, to allow firms to find their own responses to new economic and technological conditions, which is bound to give rise to greater inter-firm diversity. As firms have acquired the power to exit non-accommodating national regimes, they are likely to be heard by national governments, although apparently on capital market regulation more than on industrial relations. At the same time, multinational firms often appreciate national differences in production regimes and associated productive capacities, being able to benefit from the comparative advantages of a variety of regimes by putting together portfolios of plants located in different countries and specializing in different tasks. Sometimes, however, developing local or national advantages requires that the firms that use them can be made to accept obligations, the discharge of which may be expensive for them. But while failure of national governments to invest in infrastructural provision may cause firms to exit to other jurisdictions, [30] so may high taxes. Thus governments find themselves facing growing demands for public investment from increasingly less taxable firms which in effect encourage governments to pursue specialization in infrastructural endowment and competitive cost-cutting at the same time.

From a public policy perspective, economic success and social peace in European countries depend crucially on the cooperation of large firms with society, above all in the creation of employment, but also in opening up internal labor markets to outsiders, creating an appropriate gender and generational balance among the employed, helping integrate immigrants in work and society, making work and family compatible, and providing good training so that workers remain employable in the external labor market if a firm can no longer keep them. Firms do some of these things on their own, especially when labor markets are tight and bottlenecks in the labor supply must be overcome. But this is unlikely to be sufficient. As national regimes lose their hold on large firms, which themselves emerge as effective institution-builders and as major foci of social integration and identification, new means of public intervention in private markets and hierarchies need to be devised to make public and private purposes compatible and safeguard the social sustainability of a competitive economy. Here close cooperation and a new division of labor between firms and public authorities are required, of a sort of which we know little as yet. 


\section{Convergence, Comparative Advantage, and Strategic Choice: Corporate Change Under Uncertainty}

In trying to sum up what we seem to know about the dynamics of change in corporate organization in Europe today, it is fruitful to distinguish between the levels of the firm and that of national regimes, if only because it is in the interaction between the two that some of the most important developments are taking place. Ten points come to mind by which the present overview may be tentatively concluded:

1. Large firms appear to be less willing than in the past to let their structures and strategies be determined by prescriptive national regimes, with respect to their relations to shareholders as well as, to a lesser extent, to workforces. In the more turbulent, politically less protected economic environment of today, "strategic choice", as first discovered by the U.S. industrial relations literature of the late 1980s, has become a key category in accounting for the structure and behavior of large companies. As firms strive to meet their individual competitive requirements as closely as possible, corporate organization becomes more diverse within countries, with firms developing their own variants of national systems of industrial citizenship while at the same time learning to meet the behavioral requirements of a more marketized and arms-length capital nexus. Continental-European countries may as a consequence appear to become more similar both to each other and to the AngloAmerican world, in that they lose some of their previous capacity to impose relatively uniform corporate governance and labor relations arrangements on national firms, having to allow the latter de facto or de jure greater freedom to follow what they individually perceive as their relevant market signals. To this extent it seems justified to speak of a movement towards cross-national convergence at the regime level.

2. Growing diversity between firms within national regimes may amount to declining diversity between firms across national borders, as a result of adaptation of corporate strategies and structures to jointly experienced international market pressures. Indeed at the same time as firms gain in freedom from national regulation, we seem to observe a narrowing of their range of strategic alternatives. For example, firms increasingly give up export-oriented strategies of internationalization in favor of locating production in foreign countries. Also, as firms come under intensified competitive pressure, they all apply more stringent methods to assess the profitability of their operations, frequently in the form of shareholder value-oriented management. Introduction of the latter is, of course, also caused by the need to satisfy more demanding - institutional - investors. Pressures of this sort for cross-national convergence between firms originate both in capital markets and, within sectors, in product markets.

3. At the same time, there still is considerable diversity between firms, in terms of both strategy and structure. For example, no single "best practice" seems to be emerging with respect to the management of internationalizing or multinational operations. In particular, expectations that multinational firms will all develop a territorial-divisional matrix organization seem to have not materialized. The apparent absence of a universally preferred model, which corresponds to the increased autonomy of firms, and the observed variety in the management structures of multinational firms may reflect nothing more than a prolonged period of uncertainty and experimentation. It may also mean, however, that the optimal solution to the problems of managing internationalization is indeterminate or conditional on a firm's history, including its country of origin, so that functionally equivalent but otherwise different responses 
4. Another source of diversity between firms appears to be the resilience of national industrial relations and industrial citizenship arrangements. Comparatively sticky national labor regimes force firms to invent new ways of reconciling their traditional relations to worker stakeholders with the demands of new shareholders pressing for "shareholder value". To the extent that national labor regimes constrain company strategies and structures more than national capital market regimes, adjustment to shareholder value is bound to take place in national colors, even though, as has been pointed out, labor regimes are themselves being idiosyncratically re-defined at firm level and thereby internally diversified. As firms subject to relatively "rigid" labor regimes adjust to new capital markets, they may try to discover capital market niches in which types of financial performance that are compatible with their industrial citizenship regime are rewarded, enabling them to survive without having to adopt a convergent, standard response to shareholders that might jeopardize the stability of their labor relations. In this respect, convergence would occur only in the sense of all firms alike trying to develop individualized responses to new challenges that fit their specific national legacies and productive capabilities best.

5. More generally, even the most multinational companies, with perhaps a few exceptions, seem remain clearly identifiable in terms of their country of origin, for example with respect to preferred management practices at their headquarters or to differential prospects of internal advancement for managerial staff from different countries. National differences may further contribute to differences between multinational firms through the latter's strategic choices as to the location of their operations in the national settings that compose their international environment. A multinational company can be seen as a collection of national subsidiaries held together by a nationally identifiable center and assembled, not just for the firm to be present in key markets, but also to take advantage of the specific productive capabilities associated with different national locations and, by implication, national institutional arrangements. Multinational companies, in other words, may be regarded as portfolios of different productive capacities and opportunities offered by different countries, and in this sense as distinctive combinations of national economic, organizational and cultural characteristics .

6. As national regimes can no longer protect national firms from international competition, firms demand that they be softened up, so as to allow individual firms greater freedom to adapt to new and changing product, capital and labor market environments. In this sense it is true case that firms are pressing for convergence of regimes, in the sense of universal liberalization, as a precondition for themselves to diverge with respect to their structural and strategic responses to new competitive conditions. However, apart from the fact that in Continental-European countries, this raises issues of accountability to public interests and of political stability in terms of industrial relations, it may also affect the different productive capacities and proclivities supported by different national institutions. While clearly there is a long way from supervisory board co-determination to "diversified quality production", or from insider finance to excellence in incremental innovation, indications are that certain capital and labor market regimes are conducive to certain kinds of economic performance, endowing the firms subject to them with specific comparative advantages. To the extent that the distinctiveness of national regimes may be rooted in institutionalized obligations for market participants that would fall by the wayside in the course of convergent liberalization, the latter would erode, not just the regimes, 
but also the comparative advantages firms may derive from them. At this point the interest of firms, even those operating in international markets, in liberal convergence of national regimes become less than unambiguous.

7. Pressures by firms on national regimes for liberalization are mitigated by the fact that firms operating under given rules and institutions may have adjusted to them over time, in the sense of having learned to make the best of them and, in the ideal case, turn the constraints they represent into opportunities. For example, firms subject to co-determination, which have to offer their workforces stable employment, may have acquired a habit to invest heavily in workforce training, in an effort to specialize in high-quality products for market niches in which price competition is moderate. Investment in specialization of this sort amounts to sunk costs that militate against short-term strategic re-orientation and may make firms discount the benefits of liberalization. (Of course firms can hope to gain the same benefits they derive from collective regulation from individual efforts or from the market, but to what extent this is realistic may be uncertain.) In addition firms may be afraid of the disorder potentially associated with rapid institutional change, the economic costs of which would further detract from the potential benefits of convergence on a more liberal system.

8. Pressures for regime liberalization should be further alleviated by the possibility for internationalizing firms to shop around internationally for the optimal regimes and institutional infrastructures for specific functions or tasks. As firms become customized configurations of different national, or regional, competitive advantages, they can selectively buy themselves into the national institutional arrangements they need, which makes it less urgent for them to have their domestic institutions changed to fit their competitive requirements - provided there is sufficient "requisite variety" in their institutional environment. In the process firms may not just lose interest in cross-national convergence, but may indeed begin positively to appreciate the advantages of cross-national diversity.

9. As far as national regimes themselves are concerned, public policy faces the difficult alternative between convergent liberalization, most likely on an Anglo-American pattern, and cultivation of distinctive comparative advantages, based on industrial citizenship and public interest obligations of firms and potentially enabling the latter to specialize on selected market niches or modes of production. Neither approach is without risks. Convergence may not be achieved without significant domestic conflict, and its economic results may be uncertain given the, by definition, many competitors pursuing the same strategy. Specialization, in turn, may locate a national regime in a market niche too small for an entire economy, or one that may soon disappear; in the latter case, the institutions that have supported specialization may lose their usefulness. Between convergence and differentiation, a "third way" may be regime pluralism, with countries offering different regimes for, say, long-term and short-term oriented finance (see Mayer, in this volume). Internal diversity of this sort would be equivalent on the regime level to the mixed regime portfolios assembled by large multinational firms, and they would avoid a potentially vulnerable institutional mono-culture. The question is, however, whether and to what extent different regimes in capital or labor markets can coexist in the same country without undermining each other - in other words, whether non-liberal regimes require something like a monopoly status to produce their specific benefits.

10. Internal differentiation of national regimes, enabling them to support different 
structures and strategies of economic organizations, is often and increasingly accomplished through regional decentralization of public policy and collective labor relations. As regions specialize on particular sectors and comparative advantages, decentralization and increasing competition between regional units result, not in convergence, but in specialization. Regional autonomy and specialization seem to interact in an as yet unexplored way with the growing autonomy of firms from national regimes, as well as their desire to locate different functions in areas where they are optimally supported by local conditions and institutions.

Convergence, between firms as well as national regimes, seems far off as no one best way to international competitiveness is in sight. Corporate organization, just as technology, is today going through a period of dynamism, experimentation, and serendipitous discovery in which no ready recipes are on offer and theory has yet to catch up with reality. Internationalization proceeds while the country of origin of multinational firms remains clearly recognizable; at the same time, there is extensive eclectic hybridization of practices and structures across national borders. Both firms and national regimes seem to waver between pressures for convergence on the one hand and the promises of specialization on the other - between meeting competition head-on and, alternatively, building up distinctive capabilities others find hard to emulate. The transformation of corporate organization in Europe will for some time offer a rich field for empirical research and theory building.

\section{References}

Achleitner, Ann-Kristin, and Alexander Bassen, 2000: Entwicklungsstand des Shareholder-Value-Ansatzes in Deutschland: Empirische Befunde. EBS Finance Group Working Paper Series 00-02. Oestrich-Winkel: EBS Finance Group. Albert, Michel, 1991: Capitalisme contre capitalisme. Paris: Le Seuil.

Amelung, Torsten, 1999: Globalisierung, Conglomerate Discount und Auswirkungen auf die Unternehmensstrukturen. In: Journal für Betriebswirtschaft 1/99, 27-38.

Apeldoorn, Bastiaan van, 2000: The Rise of Shareholder Capitalism in Continental Europe? Conference paper. XVIII World Congress of the International Political Science Association, Quebec City, 1-5 August, 2000.

Becht, Marco, and Ailsa Roel, 1999: Blockholding in Europe: An International Comparison. In: European Economic Review 43, 1049-1056.

Berle, Adolf A., and Gardiner C. Means, 1999: The Modern Corporation and Private Property. With a new Introduction by Murray Weidenbaum and Mark Jensen. New Brunswick and London: Transaction Publishers.

Beyer, Jürgen, 1999: Unternehmensverflechtungen und Managerherrschaft in Deutschland. In: Leviathan 27, 518-536.

Beyer, Jürgen, 2000: "One best way" oder Varietät? Strategischer und organisatorischer Wandel von Großunternehmen im Prozess der Internationalisierung. MPIfG Discussion Paper 01/2. Cologne: Max Planck Institute for the Study of Societies.

Bispinck, Reinhard, 1997: Das Märchen vom starren Flächentarifvertrag. Eine Analyse von tariflichen Öffnungsklauseln aus über 100 Tarifbereichen. Düsseldorf: DGBTarifarchiv.

Bühner, Rolf, 1997: Increasing Shareholder Value Through Human Asset Management. In: Long Range Planning 30, 710-171.

Crouch, Colin, and Wolfgang Streeck, 1997: Introduction: The Future of Capitalist Diversity. In: Colin Crouch and Wolfgang Streeck (eds.), Political Economy of 
Modern Capitalism: Mapping Convergence and Diversity, London: Sage, 1-18. de Jong, Henk Wouter, 1997: The Governance Structure and Performance of Large

European Corporations. In: The Journal of Management and Governance 1, 5-27.

Deutsche Bundesbank, 1999: Jahresabschlüsse westdeutscher Unternehmen 1971 bis 1996. Statistische Sonderveröffentlichung 5. Frankfurt am Main: Deutsche

Bundesbank.

Donnelly, Shawn, Andrew Gamble, Gregory Jackson and John Parkinson, 2000: The Public Interest and the Company in Britain and Germany. London: Anglo-German Society for the Study of Industrial Society.

Fama, Eugene, 1980: Agency Problems and the Theory of the Firm. In: Journal of Political Economy 88, 288-307.

Gilson, Ronald J., 2000: The Globalization of Corporate Governance: Convergence of Form or Function. Columbia Law School, The Center for Law and Economic Studies Working Paper No. 174. New York: Columbia Law School.

Guillén, Mauro F., 2000: Corporate Governance and Globalization: Is There Convergence Across Countries? Advances in International Comparative Management.

Hassel, Anke, Martin Höpner, Antje Kurdelbusch, Britta Rehder and Rainer Zugehör, 2000: Zwei Dimensionen der Internationalisierung: Eine empirische Analyse deutscher Großunternehmen. In: Kölner Zeitschrift für Soziologie und Sozialpsychologie 52(3), 500-519.

Höpner, Martin, 2000a: Kapitalmarktorientierte Unternehmensführung: Messung,

Bestimmungsgründe und Konsequenzen. Conference Paper. Research Network on Corporate Governance Conference, Berlin, Wissenschaftszentrum Berlin für Sozialforschung, 22-23 June 2000.

Höpner, Martin, 2000b: Ende der Deutschland AG? In: Die Mitbestimmung 46/11, 12-16. Höpner, Martin, 2000c: Unternehmensverflechtung im Zwielicht. Hans Eichels Plan zur Auflösung der Deutschland AG. In: WSI-Mitteilungen 53, 655-663.

Höpner, Martin, 2000d: Professionalisierung, Internationalisierung, Vermarktlichung: Die soziale Welt deutscher Topmanager in den 1990er Jahren. Unpublished manuscript. Cologne: Max Planck Institute for the Study of Societies.

Höpner, Martin, and Gregory Jackson, 2000: The Political Economy of Takeovers in Germany: Institutional Change and the Case of Mannesmann. Paper Presented at the 14th International Conference of the Society for the Advancement of Socio-Economics (SASE), London, July 2000.

Jackson, Gregory, 2001a: Comparative Corporate Governance: Sociological Perspectives. In: Andrew Gamble, Gavin Kelly and J. Parkinson (eds.), The Political Economy of the Company. Oxford, UK: Hart Publishers.

Jackson, Gregory, 2001b: The Origins of Non-Liberal Corporate Governance in Germany and Japan. In: Wolfgang Streeck and Kozo Yamamura (eds.), The Origins of NonLiberal Capitalism: Germany and Japan. Ithaca, NY: Cornell University Press. Jackson, Gregory, forthcoming: Corporate Governance in Germany and Japan: Liberalization Pressures and Responses. In: Kozo Yamamura and Wolfgang Streeck (eds.), Germany and Japan: The Future of Nationally Embedded Capitalism in a Global Economy.

Jürgens, Ulrich, Joachim Rupp and Katrin Vitols, 2000: Corporate Governance and Shareholder Value in Deutschland. WZB Discussion paper FS II 00-202. Berlin: Wissenschaftszentrum Berlin für Sozialforschung.

Kommission Mitbestimmung, 1998: Mitbestimmung und neue Unternehmenskulturen: Bilanz und Perspektiven. Bericht der Kommission Mitbestimmung. Bertelsmann Stiftung und Hans-Böckler-Stiftung. Gütersloh: Verlag Bertelsmann Stiftung.

Köstler, Roland, 2000: Anforderungen der Arbeitnehmer an eine effektive Unternehmensüberwachung. Workshop paper. Workshop on "Institutioneller Wandel 
in den industriellen Beziehungen", Max Planck Institute for the Study of Societies, Cologne, December 2000.

Lang, Larry, and René Stulz, 1994: Tobin's q, Corporate Diversification and Firm Performance. In: Journal of Political Economy 102, 1248-1280.

La Porta, Rafael, Florencio Lopez-de-Silanes and Andrei Shleifer, 1998: Corporate Ownership Around the World. Cambridge, MA: National Bureau of Economic Research.

Mayer, Colin, 2001: Structures de financement et organisation des entreprises. In: Robert M. Solow, Institutions et croissance. Les chances d'un modèle économique européen. Paris: Albin Michel, 143-174.

OECD, 1997: The Impact of Institutional Investors on OECD Financial Markets. In: Financial Market Trends 68, 15-55.

Prowse, Stephen, 1994: Corporate Governance in an International Perspective: A Survey of Control Mechanisms Among Large Firms. Basle: Bank for International Settlements.

Rappaport, Alfred, 1986: Creating Shareholder Value: The New Standard for Business Performance. New York: The Free Press.

Rappaport, Alfred, and Mark Sirower, 2000: Unternehmenskauf - mit Aktien oder in bar bezahlen. In: Harvard Businessmanager, 32-46.

Rehder, Britta, 2000: Abweichung als Regel? In: Die Mitbestimmung 4/2000, 12-16. Shleifer, Andrei, and Robert W. Vishny, 1996: A Survey of Corporate Governance. NBER Working Paper No. 5554. Cambridge, MA: National Bureau of Economic Research.

Soskice, David, 1999: Divergent Production Regimes: Coordinated and Uncoordinated Market Economies in the 1980s and 1990s. In: Herbert Kitschelt et al. (eds.), Continuity and Change in Contemporary Capitalism, Cambridge: Cambridge University Press, 101-134.

Streeck, Wolfgang, 1991: On the Institutional Conditions of Diversified Quality Production. In: Egon Matzner and Wolfgang Streeck (eds.), Beyond Keynesianism: The Socio-Economics of Production and Employment, London: Edward Elgar, 21-61. Zugehör, Rainer, 2000: Die neue Macht des Kapitalmarktes: Der Einfluss des Kapitalmarktes auf das Investitionsverhalten deutscher Großunternehmen. Unpublished manuscript. Cologne: Max Planck Institute for the Study of Societies.

\section{Endnotes}

1 Paper presented at the First Conference of the Saint-Gobain Foundation for Economic Research, "What Do We Know About Institutions in the New Europe?", Paris, November 9 and 10, 2000. For empirical detail the paper draws to a large part on research by Bastiaan van Apeldoorn, Jürgen Beyer, Anke Hassel, Martin Höpner, Gregory Jackson, Britta Rehder and Rainer Zugehör at the Max Planck Institute for the Study of Societies in Cologne. I am particularly indebted to Martin Höpner for invaluable help with reading the literature and organizing the quantitative information on the German case.

2 Attempts by the Commission to enact a Directive on minimal standards for workforce participation in national firms have yet to get off the ground. If they will ever issue in legislation, the standard it will set will almost certainly be lower than in all Member countries, except perhaps the United Kingdom.

3 How international competition for employment between plants of the same company may affect the functioning of European Works Councils is an interesting question on 
which we know little. Initial evidence suggests that discussions of specific investment projects are rare, due to unbridgeable conflicts of interest, and solidarity is limited to exchange of information on ongoing decisions and "bidding procedures". This seems to be different only if managements try to play off plants against one another by using biased or false information, or if pressures for higher productivity are selectively applied to only a subset of plants.

4 In 1986, the correlation between foreign turnover and foreign employment, in per cent of a firm's total turnover and employment, was .668 for the 100 largest German firms. Ten years later, it had risen to .725 (Hassel et al. 2000).

5 As reported by The Economist (29 April 2000, p. 10), the value of European mergers and acquisitions increased from roughly $\$ 200$ billion in 1994 to 1.5 trillion in 1999, with "almost as many cross-border deals as domestic deals".

6 Privatization thus both coincided with and gave rise to a public interest in liquid stock markets and the changes in financial regulation necessary to create these.

7 Deutsche Bundesbank (1999, 139). It is, however, conceivable that shareholder value orientation was sometimes promoted by a desire to raise capital for overseas investment from local capital markets, especially the U.S.

8 The Economist estimates that cross-shareholding in Europe outside Britain declined between 1994 and 1999 from 19 to 10 percent of total stock market value (29 April 2000, p. 14). On Germany see Höpner (2000c).

9 Van Apeldoorn (2000) also observes a slow decline in the share held by traditional owners and a transformation of industrial into "money capitalists".

10 Which, in turn, are likely to fetch a higher price if the firm is credibly committed to high shareholder value.

11 Among the 100 largest German firms, shareholder value orientation is strongly related to internationalization of product markets, indicating that it may be a response in part to strong competitive pressures (Höpner 2000).

12 Also, conglomerates tend to be more shareholder value-oriented than other firms, especially if they have significant foreign ownership - very likely because they are more in need to make themselves attractive to "the markets" (Zugehör 2000).

13 In 1999, according to The Economist (29 April 2000, p. 10), the value of hostile takeovers in Europe, at $\$ 400$ billion, was four times the combined total for the years 1990 to 1998 . Over half of the hostile takeover bids were successful.

14 The story of the progress of shareholder value policies among large firms is a complex one. According to a survey among German firms, managements shifted to shareholder value not just because of pressure from shareholders - which however seems to have been the most important factor - but also to improve performance and managerial control (Achleitner and Bassen 2000). This might explain why there is a correlation between internationalization of product markets and shareholder value orientiation. Moreover, shareholder value may have become "fashionable", as indicated by a very high correlation (at $\mathrm{r}=.69$ ) between a company's shareholder value orientation and its reputation among German managers (Höpner 2000d, 29).

15 For example, the German law on Control and transparency in Enterprises (KonTraG), which was passed in mid-2000, made it illegal for firms to restrict the voting rights of particular categories of shares. In other countries, too, voting restrictions and voting caps seem to be on their way out. Overall, German legal rules on corporate governance, especially with respect to the situation of minority shareholders, have changed in a UK direction between 1996 and 1999, but still have a long way to go (Donnelly at al. 2000).

16 Apart, perhaps, from the fact that Mannesmann used to have voting caps which by the time of the takeover had become illegal.

17 The commission included, among others, the founder of Bertelsmann, Reinhard 
Mohn, the CEO of BASF, Jürgen Strube, the Presidents of the German Trade Union Confederation, Dieter Schulte, and of the Federal Labor Court, Thomas Dieterich, and the Secretary of State in the Federal Ministry of Labor, Werner Tegtmeier.

18 In 1986 turnover of large German firms in foreign markets, in percent of total turnover, was on average more than twice as high than foreign employment as a percentage of total employment. In 1996 this relationship had declined to 1.3, indicating a rapid and significant shift of production abroad, and a change in strategy away from export of home-county products (Beyer 2000).

19 In about 40 of the 100 largest German firms there was at least one formal agreement of this sort during the 1990s.

20 There also were several cases of employee buy-outs in the 1990s, under which plants or divisions of large firms that the company was planning to sell off were taken over by employees. The new firms remained at least for a while within the production network of their former mother company, which provided them with the bulk of their work or even with financial support.

21 De Jong (1997) explains the relatively low share of their value added that Continental firms have traditionally paid out to their shareholders - and the correspondingly high share that went to labor - by the presence of strong protections in national regimes of corporate governance against hostile takeovers. Among the largest German firms, the share of capital in value added increased slightly in the 1990s, and most strongly in firms with dispersed share ownership.

22 Union demands with respect to the new German takeover code focus on improved access of workforce representatives to information, especially on the intentions and business plans of the bidder, and on an obligation for management to include the views of the workforce in the official statements of the company.

23 Workforce influence may also have caused management stock option plans in European firms to be somewhat less exorbitant and inviting of opportunism that in the U.S.

24 At least one firm expanded employee stock ownership after an unfriendly takeover bid had failed in the last minute. In a number of companies employee stock owners are beginning to think about getting collectively organized to make their voice heard in the shareholder assembly. In some cases employee stock owners are represented by works councils whereas in others they are independently organized. The potential problems that may result for management if workers take an active role as stock owners - in addition to the benefits for firms in terms of better protection from hostile takeovers - are yet to be discussed; they are likely to be an important subject of future debates on the transformation of industrial citizenship.

25 On Mannesmann, and especially the reactions of the union, see Höpner and Jackson (2000), Jürgens et al. (2000).

26 The same seems to be true for regime of corporate finance. See Mayer (2000) who shows that different capital market regulations are associated with different types of economic performance and competitiveness. Indeed industrial citizenship and financial market regimes may complement each other in supporting certain types of performance, for example in diversified quality production (Jackson forthcoming; Soskice 1999).

27 To what extent social peace, worker good will and a company's social integration are positively valued by the stock market is not known and would be an interesting subject for future research (Jackson 2001a).

28 More specifically, the percentage of CEOs without an academic degree declined from the early to the late 1980s from 14 to zero; the average length of tenure fell between the early 1980s and the late 1990s from about 13 to 6.5 years; and the percentage of CEOs who had been recruited into their current position from outside 
the firm more than doubled from 17 to 36 (Höpner 2000d).

29 The strongest expression of this sort of interest was, of course, when governments nationalized firms or entire sectors, to ensure that their operation was in harmony with the interest of the community. In the twentieth century this was a frequent practice in Europe, even in the United Kingdom. Today the movement is in the opposite direction as formerly public sectors have been and continue to be privatized on a large scale. Very appropriately, a major issue in the privatization debate is how to ensure that privatized utilities continue to provide a minimum of "public service" even where this is not necessarily profitable.

30 In one out of ten large industrial firms in Germany that have in the 1990s signed agreements with their works councils on employment and investment, the government was involved in the negotiations offering subsidies or contributing land or infrastructural investment to help the two sides come to an agreement.

Copyright (C) 2001 Wolfgang Streeck

No part of this publication may be reproduced or transmitted without permission from the author. Jegliche Vervielfältigung und Verbreitung, auch auszugsweise, bedarf der Zustimmung des Autors. MPI für Gesellschaftsforschung, Paulstr. 3, 50676 Köln, Germany 